\title{
Development and Validation of Analytical Method for Sulfonamide Residues in Eggs by Liquid Chromatography Tandem Mass Spectrometry based on the Comission Decision 2002/657/EC
}

\author{
Márcia N. S. de la Cruz, ${ }^{*, a}$ Renata F. Soares, ${ }^{a}$ Anna Sylvia F. Marques ${ }^{b}$ and \\ Francisco Radler de Aquino-Neto ${ }^{a}$ \\ ${ }^{a}$ LADETEC-Instituto de Química, Universidade Federal do Rio de Janeiro, \\ Av. Athos da Silveira Ramos, 149, Bl. A, sl. 607, Ilha do Fundão, Cidade Universitária, \\ 21941-909 Rio de Janeiro-RJ, Brazil \\ ${ }^{b}$ Applied Biosystems do Brasil, Av. do Café, 277, Torre B, $1^{\circ}$ andar, 04311-000 São Paulo-SP, Brazil
}

\begin{abstract}
A técnica de cromatografia líquida acoplada a um espectrômetro de massas com ionização "electrospray" (LC-ESI-MS/MS) foi usada para a determinação simultânea de resíduos de dez sulfonamidas (SAs: sulfacetamida, sulfatiazol, sulfamerazina, sulfametazina, sulfametoxipiridazina, sulfametazol, sulfacloropiridazina, sulfametoxazol, sulfadimetoxina e sulfaquinoxalina) em ovos. As amostras foram preparadas por precipitação das proteínas com acetonitrila seguida por extração em fase sólida. Após remoção do solvente e reconstituição, os extratos finais foram injetados no LC-ESI-MS/MS no modo positivo para todas as sulfonamidas. O método validado resultou em recuperação entre 87 e $116 \%$ com desvios padrão relativo entre 8,5 e 27,2\%, CC $\alpha$ entre 101,0 e $122,1 \mathrm{ng} \mathrm{g}^{-1}$ e CC $\beta$ entre 114,5 e 138,8 $\mathrm{ng} \mathrm{g}^{-1}$. O método analítico, no qual foram utilizadas amostras fortificadas, foi validado baseado na Decisão da Comissão 2002/657/CE.
\end{abstract}

Liquid chromatography- electrospray ionization - tandem mass spectrometry (LC-ESI-MS/MS) was used to simultaneous determination of ten sulfonamide (SAs) residues (sulfacetamide, sulfathiazole, sulfamerazine, sulfamethazine, sulfamethoxypyridazine, sulfamethizole, sulfachloropyridazine, sulfamethoxazole, sulfadimethoxine and sulfaquinoxaline) in eggs. Samples were extracted with acetonitrile and the supernatants were cleaned up by solid phase extraction. After solvent evaporation and reconstitution, aliquots of the final extracts were injected into a LC-ESI-MS/MS in positive mode for all sulfonamides. The validated method resulted in recoveries ranging between 87 and $116 \%$ with relative standard deviations between 8.5 and $27.2 \%, \mathrm{CC} \alpha$ between 101.0 and $122.1 \mathrm{ng} \mathrm{g}^{-1}$, and CC $\beta$ between 114.5 and $138.8 \mathrm{ng} \mathrm{g}^{-1}$. The analytical method, using fortified samples, was validated based on the Commission Decision 2002/657/EC.

Keywords: sulfonamides, egg, SPE, LC-MS/MS

\section{Introduction}

Sulfonamides (SAs) are synthetic antimicrobial compounds with the common structure $p$-amino-benzenesulfonamide (Figure 1) and they are widely used against several infections. These antimicrobials act by competing with $p$-amino-benzoic acid in the enzymatic synthesis of dihydrofolic acid, decreasing reduced folates that are essential in nucleic acids synthesis. The use of sulfonamides decreased with the advent of peniciline, but they are still widely employed as veterinary medicines to treat a variety

*e-mail: marcianogueira@iq.ufrj.br of bacterial and protozoan infections in cattle, swine and poultry. In recent years, there is an increasing concern about sulfonamide residues in food products since a study demonstrated that these substances are carcinogenic and may reduce the therapeutic effectiveness of drugs on humans. ${ }^{1}$ To ensure the safety of food for humans, the European Union (EU) has established maximum residue limit (MRL) of $100 \mathrm{ng} \mathrm{g}^{-1}$ for total sulfonamides in foodstuffs. There is no MRL established in Brazil for eggs yet, so in this work it was adopted $100 \mathrm{ng} \mathrm{g}^{-1}$ for total SAs according to the EU.

Sulfonamides have high polarity and low volatility, hence liquid chromatography is the most appropriate 


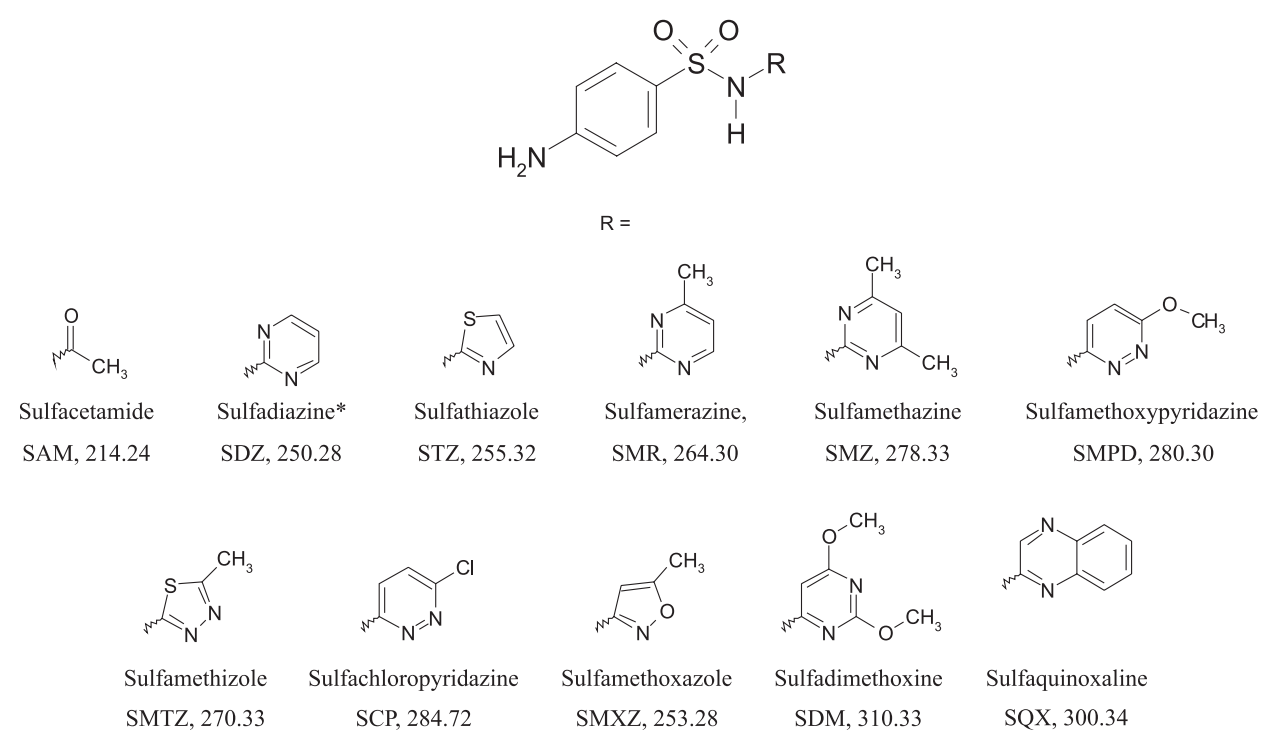

Figure 1. Chemical structures, names, acronyms and molecular weights of sulfonamides studied. *Internal standard.

technique of analysis. There are methods that use high performance liquid chromatography (HPLC) with fluorescence detector, ${ }^{2-6}$ or with ultra-violet (UV) detector, ${ }^{7-10}$ or else with diode array detector (DAD), ${ }^{11-27}$ but mass spectrometer (MS) detectors are the most appropriate because they give enough information for molecular identification.

Several LC-MS methods were published for sulfonamide residues in foodstuffs, ${ }^{28-39}$ and they presented some sample preparation techniques with different kinds of analyzers and sources. Some methods using LC-MS/MS are available in the literature. ${ }^{40-52}$ Additionally, there are studies that use MS to analyze eggs, which are a very popular protein source. ${ }^{38,39,53,54}$ These studies used electrospray ion source (ESI), that is a good interface for sulfonamides, but two of them used a single quadrupole as analyzer. It is more appropriate to use quadrupoles in tandem or an ion trap analyzer, because they allow sequential mass spectrometry experiments that enhance selectivity and sensitivity. All methods using mass spectrometry filters in tandem to analyze eggs on regulated laboratories should be according to the Commission of the European Communities, Commission Decision 2002/657/EC that implements Council Directive 96/23/EC concerning the performance of analytical methods and the interpretation of results. ${ }^{55}$

The purpose of this study was to develop an analytical method using high performance liquid chromatography with a tandem mass spectrometer (LC-MS/MS) as detector, equipped with electrospray ionization with a triple quadrupole analyzer, and validate it based on 2002/657/EC, to identify and quantify simultaneously 10 sulfonamide residues (Figure 1) in whole eggs (yolk and white). LC-MS/MS system used in this work allowed solvent flows of $1 \mathrm{~mL} \mathrm{~min}{ }^{-1}$, which is uncommon. All the LC conditions were developed in a HPLC system and then applied to the LC-MS/MS, without any modification, resulting in two advantages: less time of use of LC-MS/MS and having a method for screening (HLPC-DAD) and for confirmation (LC-MS/MS).

\section{Experimental}

\section{Chemicals and material}

Sulfadimetoxine (SDM), sulfamethazine (SMZ), sodium sulfaquinoxaline (SQXNa), sulfacetamide (SAM), sulfachloropyridazine (SCP), sulfadiazine (SDZ) (internal standard), sulfamerazine (SMR), sulfamethizole (SMTZ), sulfamethoxazole (SMXZ), sulfathiazole (STZ) and sulfamethoxypyridazine (SMPD) were purchased from Sigma-Aldrich (Steinheim, Germany). Sulfadiazine was adopted as the internal standard (IS) because it is not a target sulfonamide for eggs and it has different retention time from the others. Acetonitrile HPLC grade was from TEDIA (Fairfield, USA) for extraction procedure and from J. T. Baker (Mexico City, Mexico) for mobile phase. Formic acid from J. T. Baker (Phillipsburg, New Jersey, USA) was used to acidify mobile phases. Pesticide grade methanol was obtained from TEDIA (Fairfield, USA) for extraction procedures. Distilleddeionized water was generated in-house from a Milli-Q-Plus water system. Bond Elut $\mathrm{C}_{18}(200 \mathrm{mg})$ solid phase extraction (SPE) cartridges were obtained from Varian (Palo Alto, USA) and the solid-phase extraction vacuum manifold from Supelco (Bellefonte, USA). Turbo Vap LV solvent evaporator ZYMARK (Hopkinton, USA), mixer Walita (São Paulo, Brazil), electronic analytical balance A 2005 SARTORIUS 
(Goettingen, Germany), vortex THERMOLYNE (Iowa, USA), centrifuge ZENTRIFUGEN (Kirchlenger, Germany) and automatic pipette Eppendorf (Hamburg, Germany) were used for sample preparation.

\section{LC-MS/MS system}

The liquid chromatography system was Shimadzu Prominence SIL-20AC (Maryland, USA) with binary pump Prominence LC-20AB (Maryland, USA), degasser Prominence DGU-20A 3 (Maryland, USA), autosampler Prominence (Maryland, USA), oven Prominence CTO-20AC (Maryland, USA) and spectrometer detector API 5000 from Applied Biosystems/MDS Sciex (Toronto, Canada) equipped with TurboV ${ }^{\mathrm{TM}}$ ionization source operating in a positive mode. All the data were processed in the software Analyst ${ }^{\mathbb{B}}$ version 1.4.2. Harvard infusion apparatus (Holliston, MA, EUA) was used to optimize MS conditions.

Sulfonamides were separated in a reversed phase column $\mathrm{C}_{18} 150 \times 4.6 \mathrm{~mm}, 5 \mu \mathrm{m}$, X-Terra, Waters (Milford, USA).

\section{Preparation of standard solution}

Stock solutions (SS) of individual standards were prepared by dissolving each sulfonamide in pesticide grade methanol at a concentration of $1 \mathrm{mg} \mathrm{mL}^{-1}$, except sulfaquinoxaline sodium salt, that was prepared in purified water.

Individual intermediate solutions at $0.1 \mathrm{mg} \mathrm{mL}^{-1}$ were prepared in pesticide grade methanol by diluting 1:10 the SS .

Individual work solutions (WS) were prepared at $0.01 \mathrm{mg} \mathrm{mL}^{-1}$ in purified water by diluting $1: 10$ the individual intermediate solutions.

A mix solution was prepared by combining $1 \mathrm{~mL}$ of each WS (except SDZ), resulting in a final concentration of $1 \mathrm{ng} \mu \mathrm{L}^{-1}$. All the solutions were stored at $-14{ }^{\circ} \mathrm{C}$.

\section{Sample preparation}

Eggs were purchased from the local market and blended (without shell) in a common mixer for 5 min with maximum speed. Blended eggs were stored in cold chamber at $-15^{\circ} \mathrm{C}$, when not used.

\section{Extraction procedure}

Blended eggs $1 \mathrm{~g}$ aliquots were fortified with variable volumes of mix solution and with a constant volume of IS solution, resulting in concentrations of $0,50,100,150$ and $200 \mathrm{ng} \mathrm{g}^{-1}$ for all sulfonamides (except SDZ) and $100 \mathrm{ng} \mathrm{g}^{-1}$ for IS (SDZ). After fortification, samples rested for $15 \mathrm{~min}$, and then acetonitrile $(3 \mathrm{~mL})$ was added. The mixtures were vortexed and centrifuged at $3000 \mathrm{~g}$ for $10 \mathrm{~min}$ at $0-4{ }^{\circ} \mathrm{C}$. Supernatants were separated. Acetonitrile $(1 \mathrm{~mL})$ was added to the pellets and they were centrifuged again. Both supernatants were mixed. Purified water $(0.6 \mathrm{~mL})$ was added to the combined supernatants and their volumes were reduced to $1 \mathrm{~mL}$ under nitrogen stream at $40-45^{\circ} \mathrm{C}$. The mixtures were passed through a SPE $\mathrm{C}_{18}$ cartridge previous conditioned with acetonitrile and water $(2 \mathrm{~mL}$ and $4 \mathrm{~mL}$, respectively). Sulfonamides were eluted with $3 \mathrm{~mL}$ of acetonitrile. All the SPE procedures were performed under vacuum in a manifold system with 2 drops $\mathrm{s}^{-1}$ flow.

Purified water $(0.2 \mathrm{~mL})$ was added to the eluates, they were vortexed and the volumes reduced to about $200 \mu \mathrm{L}$ under nitrogen stream at $40-45^{\circ} \mathrm{C}$. Extracts were transferred to vials, diluted with mobile phase (1:500) and injected into the LC analytical column.

\section{Chromatographic conditions}

Mobile phase was ultrapure water (A) and acetonitrile (B), both with $0.1 \%$ of formic acid, with a constant flow of $1 \mathrm{~mL} \mathrm{~min}^{-1}$. Gradient elution started with $100 \%$ of A, then decreased to $50 \%$ in $10 \mathrm{~min}$, returning to $100 \%$ in $1 \mathrm{~min}$ and remaining in $100 \%$ for $1 \mathrm{~min}$. Total time was $12 \mathrm{~min}$. Column temperature was set at $30^{\circ} \mathrm{C}$ to avoid changing in retention times and $20 \mu \mathrm{L}$ of each sample were injected.

\section{MS/MS analysis}

An API 5000 triple quadrupole mass spectrometer was operated in multiple reaction monitoring mode (MRM), with two monitored transitions for each sulfonamide for screening and quantitative analysis in a positive mode. In this study the dwell time to monitor the $22 \mathrm{MRM}$ transitions was used at $60.0 \mathrm{~ms}$.

All detector parameters were optimized with standard solutions of $10 \mathrm{ng} \mathrm{mL}^{-1}$ infused at $10 \mu \mathrm{L} \mathrm{min}^{-1}$ through a syringe pump for better response of the target sulfonamides of this study. The ion source optimized parameters were: curtain gas (CUR) 15 psi; ion spray voltage (IS) $5500 \mathrm{~V}$; nebulizer gas (GS 1) $50 \mathrm{psi}$; turbo heater gas (GS 2) $50 \mathrm{psi}$ and temperature (TEM) $750^{\circ} \mathrm{C}$. The $\mathrm{CAD}$ (collisionaly activated dissociation) gas was fixed in 12 psi.

\section{Results and Discussion}

\section{Extraction}

The whole egg (without shell) was used as sample because a previous study showed no difference between sulfonamide compounds in yolk and in white, ${ }^{56}$ being, both 
usually consumed together. This extraction method was based on the study of Heller, ${ }^{53}$ where $5 \mathrm{~g}$ of egg was used. Homogenized whole eggs ( 1 and $5 \mathrm{~g}$ ) were tested and the first resulted in a shorter procedure total time, since the time to reduce volume under nitrogen stream is shorter. Using $1 \mathrm{~g}$ of egg it resulted in $4 \mathrm{~h}$ to prepare a sample and less solvent consumption.

\section{Optimization of the MS conditions}

The ionization source was TurboV $\mathrm{V}^{\mathrm{TM}}$, that provides electrospray ionization (ESI) and allows high flow rates with no split and used in positive ionization mode. The fragments were generated in the Q2 quadrupole, colliding with $\mathrm{N}_{2}$ (ultra high purity nitrogen), called CAD gas. Q2 quadrupole is the LINAC $^{\circledR}$ (Linear Accelerator) that prevents contamination and eliminates cross-talk during the analysis, leading to a high throughput MRM. ${ }^{57}$

The MS parameters optimized were: declustering potential (DP), collision energy (CE) and cell exit potential (CXP) that were optimized for each molecule, because they are compound-dependent parameters for MS/MS analysis. These voltages are respectively related to the energy to attract positive ions to the mass spectrometer inlet, specific energy to promote fragmentation of the precursor ion in Q2 and energy to extract fragment ions from the collision chamber. Table 1 describes retention times, precursor ion, product ion, declustering potential, collision energy, cell exit potential and dwell time for each sulfonamide.

The ion source optimized parameters were: curtain gas (CUR), ion spray voltage (IS), nebulizer gas (GS 1), turbo heater gas (GS 2), and temperature from the source ceramic heaters (TEM).

Retention times were different for all sulfonamides (see Figure 2), supported by gradient elution appropriate to separate eleven sulfonamides, considering the selective MS detector. All the retention times were reproducible.

Spectra showed the common product ions $\mathrm{m} / \mathrm{z}$ 92, 108 and 156, indicating a well defined fragmentation profile (Figure 3), that had already been studied..$^{28}$ Others fragments are the result from different groups (R) from each sulfonamide. Sulfadimethoxine and sulfaquinoxaline presented the most intense molecular signals. It was necessary to monitor at least 2 MRM transitions for each sulfonamide, one to quantify (quantifier MRM) and another to qualify results (qualifier MRM), according to the European Regulations of Analytical Methods of Results..$^{58}$ The 2 MRM transitions make LC-MS/MS using triple quadrupole mass filter an auto confirmatory technique. The MRM transition $[\mathrm{M}-\mathrm{H}]^{+}>m / z, 156$ was used to quantify most of the sulfonamides, except sulfamerazine, sulfamethazine and sulfamethoxazole, because the MRM transitions used

Table 1. Sulfonamides data acquisition parameters for LC-ESI-MS/MS

\begin{tabular}{|c|c|c|c|c|c|c|}
\hline Sulfonamide & $\mathrm{t}_{\mathrm{R}}(\min )$ & Precursor ion (Q1) & Product ion (Q3) & $\mathrm{DP}(\mathrm{V})$ & $\mathrm{CE}(\mathrm{V})$ & $\mathrm{CXP}(\mathrm{V})$ \\
\hline Sulfacetamide & $\begin{array}{l}5.0 \\
5.0\end{array}$ & $\begin{array}{l}215.10 \\
215.10\end{array}$ & $\begin{array}{c}156.10 \\
92.00\end{array}$ & $\begin{array}{l}66.0 \\
66.0\end{array}$ & $\begin{array}{l}15.0 \\
31.0\end{array}$ & $\begin{array}{l}24.0 \\
20.0\end{array}$ \\
\hline Sulfadiazine* & $\begin{array}{l}5.5 \\
5.5\end{array}$ & $\begin{array}{l}251.13 \\
251.13\end{array}$ & $\begin{array}{c}156.00 \\
92.00\end{array}$ & $\begin{array}{l}40.0 \\
40.0\end{array}$ & $\begin{array}{l}23.0 \\
37.0\end{array}$ & $\begin{array}{l}34.0 \\
20.0\end{array}$ \\
\hline Sulfathiazole & $\begin{array}{l}5.9 \\
5.9\end{array}$ & $\begin{array}{l}256.06 \\
256.06\end{array}$ & $\begin{array}{c}156.00 \\
92.10\end{array}$ & $\begin{array}{l}46.0 \\
46.0\end{array}$ & $\begin{array}{l}23.0 \\
37.0\end{array}$ & $\begin{array}{l}34.0 \\
20.0\end{array}$ \\
\hline Sulfamerazine & $\begin{array}{l}5.9 \\
5.9\end{array}$ & $\begin{array}{l}265.00 \\
265.00\end{array}$ & $\begin{array}{c}108.00 \\
65.00\end{array}$ & $\begin{array}{l}76.0 \\
81.0\end{array}$ & $\begin{array}{l}47.0 \\
47.0\end{array}$ & $\begin{array}{l}22.0 \\
22.0\end{array}$ \\
\hline Sulfamethazine & $\begin{array}{l}6.4 \\
6.4\end{array}$ & $\begin{array}{l}279.20 \\
279.20\end{array}$ & $\begin{array}{c}92.10 \\
124.00\end{array}$ & $\begin{array}{l}61.0 \\
61.0\end{array}$ & $\begin{array}{l}45.0 \\
31.0\end{array}$ & $\begin{array}{l}20.0 \\
18.0\end{array}$ \\
\hline Sulfamethoxypyridazine & $\begin{array}{l}6.8 \\
6.8\end{array}$ & $\begin{array}{l}281.14 \\
281.14\end{array}$ & $\begin{array}{c}156.10 \\
92.00\end{array}$ & $\begin{array}{l}91.0 \\
91.0\end{array}$ & $\begin{array}{l}23.0 \\
41.0\end{array}$ & $\begin{array}{l}32.0 \\
38.0\end{array}$ \\
\hline Sulfamethizole & $\begin{array}{l}7.0 \\
7.0\end{array}$ & $\begin{array}{l}271.13 \\
271.13\end{array}$ & $\begin{array}{c}155.80 \\
92.00\end{array}$ & $\begin{array}{l}36.0 \\
36.0\end{array}$ & $\begin{array}{l}19.0 \\
41.0\end{array}$ & $\begin{array}{l}34.0 \\
22.0\end{array}$ \\
\hline Sulfachloropyridazine & $\begin{array}{l}7.9 \\
7.9\end{array}$ & $\begin{array}{l}285.10 \\
285.10\end{array}$ & $\begin{array}{c}156.00 \\
92.10\end{array}$ & $\begin{array}{l}66.0 \\
66.0\end{array}$ & $\begin{array}{l}21.0 \\
35.0\end{array}$ & $\begin{array}{l}20.0 \\
18.0\end{array}$ \\
\hline Sulfamethoxazole & $\begin{array}{l}8.3 \\
8.3\end{array}$ & $\begin{array}{l}254.07 \\
254.07\end{array}$ & $\begin{array}{c}92.00 \\
156.10\end{array}$ & $\begin{array}{l}71.0 \\
71.0\end{array}$ & $\begin{array}{l}39.0 \\
21.0\end{array}$ & $\begin{array}{l}36.0 \\
22.0\end{array}$ \\
\hline Sulfadimethoxine & $\begin{array}{l}9.6 \\
9.6\end{array}$ & $\begin{array}{l}311.14 \\
311.14\end{array}$ & $\begin{array}{l}156.00 \\
108.00\end{array}$ & $\begin{array}{l}66.0 \\
66.0\end{array}$ & $\begin{array}{l}29.0 \\
39.0\end{array}$ & $\begin{array}{l}24.0 \\
22.0\end{array}$ \\
\hline Sulfaquinoxaline & $\begin{array}{l}9.9 \\
9.9\end{array}$ & $\begin{array}{l}301.00 \\
301.00\end{array}$ & $\begin{array}{l}156.00 \\
108.00\end{array}$ & $\begin{array}{l}46.0 \\
46.0\end{array}$ & $\begin{array}{l}23.0 \\
33.0\end{array}$ & $\begin{array}{l}22.0 \\
22.0\end{array}$ \\
\hline
\end{tabular}

*Internal standard. Dwell time was 60.0 for all sulfonamides. 


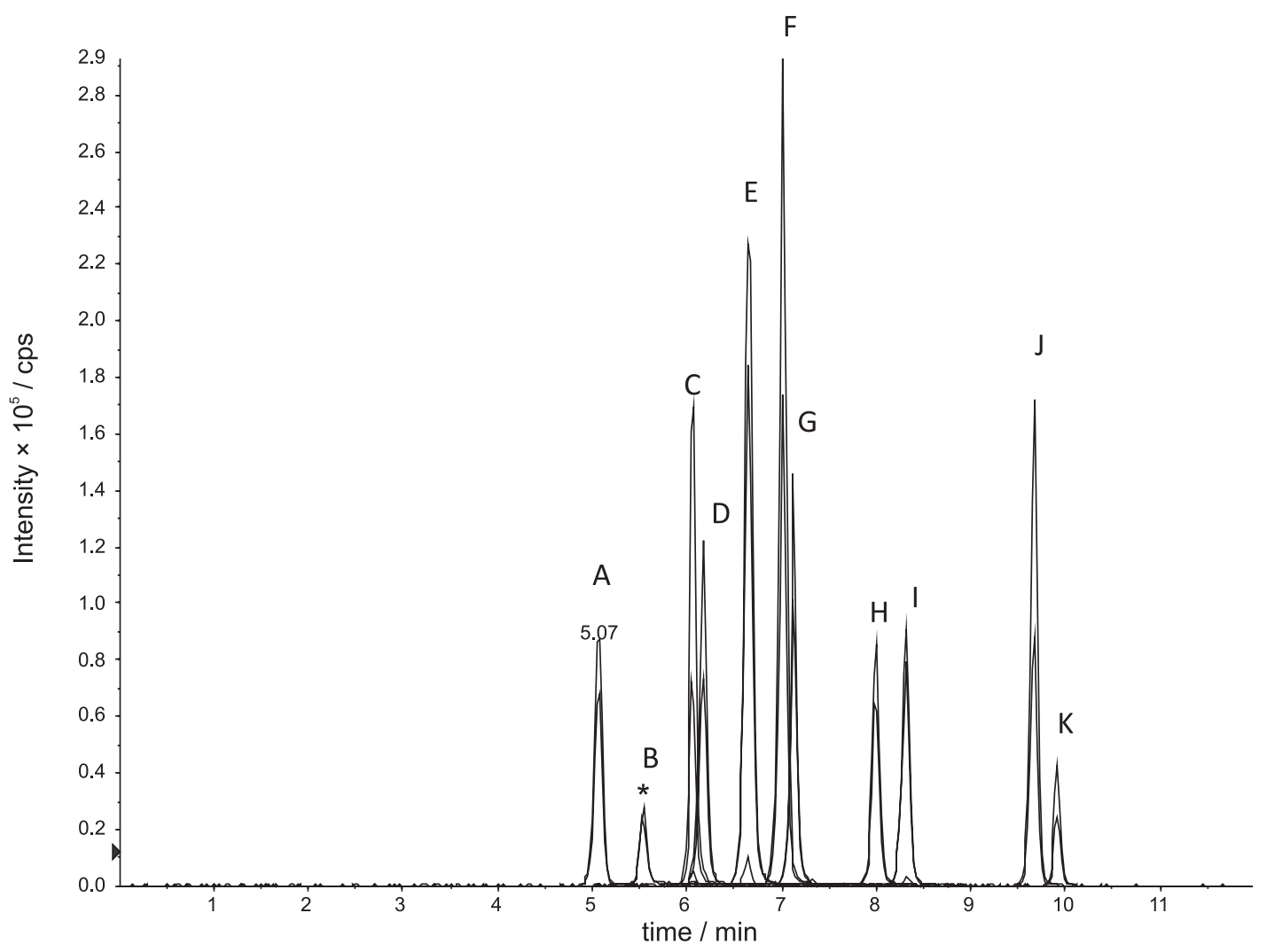

Figure 2. Chromatogram of all target compounds and internal standard $\left(\mathrm{C}_{18}\right.$ column $150 \times 4.6 \mathrm{~mm}, 5 \mu \mathrm{m}$; gradient elution with water and acetonitrile both with $0.1 \%$ of formic acid; flow of $1 \mathrm{~mL} \mathrm{~min}^{-1}$ ). A- SAM; B- SDZ*; C- STZ; D- SMR; E- SMZ; F- SMPD; G- SMTZ; H- SCP; I- SMXZ; J- SDM; K- SQX. *Internal standard.

were, $\mathrm{m} / \mathrm{z} 265.00>\mathrm{m} / \mathrm{z} 108.00, \mathrm{~m} / \mathrm{z} 279.20>\mathrm{m} / \mathrm{z} 92.10$ and $m / z 254.07>m / z, 92.00$, respectively.

Tests were done to verify ion suppression and matrix effects. The first effect can suppress ion signals because of ionization competition in the source housing decreasing target analyte signals, but this was not observed in the retention time range of the target sulfonamides. However, it was observed a matrix effect, because the slopes of the calibration curves with the matrix were different from those without the matrix. Although there was a matrix effect, it was not significant because all calibration curves for validation were performed with fortified eggs. Slope results are in Table 2.

\section{Validation}

One analyst did the validation in two days, and another analyst did it in one day, and all the procedures were based on Commission Decision 2002/657/EC. ${ }^{55}$ It consisted in analysis of the following performance criteria: specificity, linearity, accuracy, decision limit $(\mathrm{CC} \alpha)$, and detection capability $(\mathrm{CC} \beta)$.

Twenty eggs were analyzed and none presented sulfonamides signal, indicating that the method is specific.
Just the fortified sample presented the monitored ions. These blank eggs were blended and this mixture was used as sample. Linearity was determined after construction of calibration curves with fortified samples at $0,0.5,1,1.5$ and $2 \times$ MRL. Calibration curves were prepared with 3 fortified samples for each level (5 total level), resulting in 15 samples. These samples had the same internal standard concentration and variable concentration of the target sulfonamides. It was used the ratio of analyte area and internal standard area. Linearity was determined by the linear regression model. Average correlation coefficient was 0.99 for all targets. Accuracy was expressed by recovery and precision. Recovery was obtained with fortified samples at $0.5,1$, and $1.5 \times \mathrm{MRL}$ and the results were calculated using the calibration curves. In this case, three new samples were prepared for each level, and three samples results from calibration curve (linearity) were used at this stage, resulting in six samples for each level. Recovery $\%$ was calculated using the mean recovery-corrected concentration, multiplied by 100 and divided by nominal values. Precision was the relative standard deviation. Recovery and precision results are in Table 2 . The same procedure for linearity and accuracy was repeated by the first analyst in the second day and by the second analyst. 


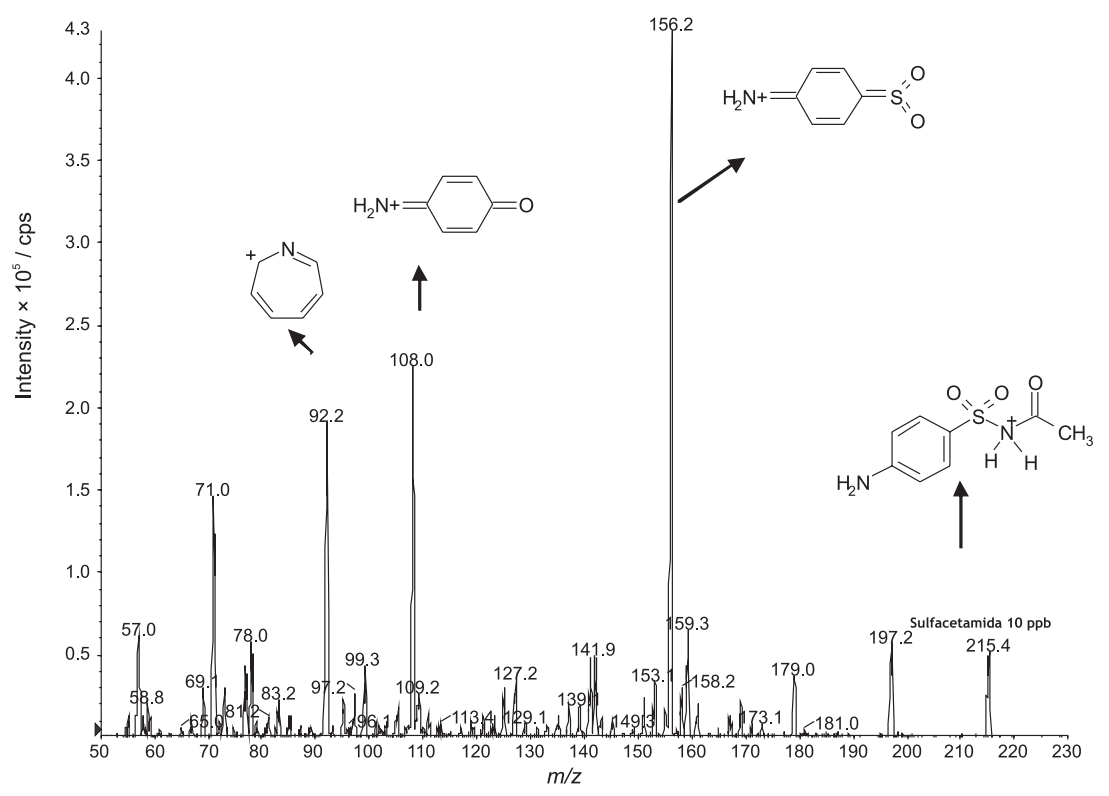

Figure 3. Triple quadrupole ESI-MS/MS spectra for sulfacetamide with commom fragments $\mathrm{m} / \mathrm{z}, 92,108$ and 156.

Table 2. Target sulfonamides recovery and repeatability data for their analysis with LC-ESI-MS/MS $\left(\mathrm{C}_{18}\right.$ column $150 \times 4.6 \mathrm{~mm}$, $5 \mu \mathrm{m}$; gradient elution with water and acetonitrile both with $0.1 \%$ of formic acid; flow of $1 \mathrm{~mL} \mathrm{~min}^{-1}$ )

\begin{tabular}{|c|c|c|c|c|c|}
\hline$\underline{\text { Sulfonamide }}$ & Concentration $\left(\mathrm{ng} \mathrm{g}^{-1}\right)$ & $\begin{array}{c}\text { Recovery } \% \\
\text { Average }\end{array}$ & $\begin{array}{c}\text { Repeatability \% } \\
\text { Average }\end{array}$ & Slope a & Slope b \\
\hline Sulfacetamide & $\begin{array}{r}50.00 \\
100.00 \\
150.00\end{array}$ & $\begin{array}{l}101.68 \\
105.36 \\
101.15\end{array}$ & $\begin{array}{l}16.63 \\
10.12 \\
16.83\end{array}$ & 0.83 & 0.01 \\
\hline Sulfathiazole & $\begin{array}{r}50.00 \\
100.00 \\
150.00\end{array}$ & $\begin{array}{r}103.93 \\
91.55 \\
90.88\end{array}$ & $\begin{array}{l}18.09 \\
11.76 \\
20.84\end{array}$ & 1.34 & 0.01 \\
\hline Sulfamerazine & $\begin{array}{r}50.00 \\
100.00 \\
150.00\end{array}$ & $\begin{array}{r}101.75 \\
89.23 \\
94.06\end{array}$ & $\begin{array}{l}11.85 \\
14.86 \\
21.23\end{array}$ & 0.98 & 0.01 \\
\hline Sulfamethazine & $\begin{array}{r}50.00 \\
100.00 \\
150.00\end{array}$ & $\begin{array}{r}109.55 \\
88.52 \\
91.04\end{array}$ & $\begin{array}{l}17.99 \\
10.35 \\
15.03\end{array}$ & 2.21 & 0.03 \\
\hline Sulfamethoxypyridazine & $\begin{array}{r}50.00 \\
100.00 \\
150.00\end{array}$ & $\begin{array}{c}107.36 \\
90.91 \\
92.62\end{array}$ & $\begin{array}{r}20.77 \\
9.58 \\
22.57\end{array}$ & 2.29 & 0.03 \\
\hline Sulfamethizole & $\begin{array}{r}50.00 \\
100.00 \\
150.00\end{array}$ & $\begin{array}{l}95.66 \\
87.52 \\
93.22\end{array}$ & $\begin{array}{r}11.39 \\
8.54 \\
11.28\end{array}$ & 1.20 & 0.01 \\
\hline Sulfachloropyridazine & $\begin{array}{r}50.00 \\
100.00 \\
150.00\end{array}$ & $\begin{array}{l}95.54 \\
89.39 \\
96.05\end{array}$ & $\begin{array}{l}14.70 \\
11.65 \\
15.76\end{array}$ & 0.77 & 0.01 \\
\hline Sulfamethoxazole & $\begin{array}{r}50.00 \\
100.00 \\
150.00\end{array}$ & $\begin{array}{r}104.13 \\
87.71 \\
98.51\end{array}$ & $\begin{array}{l}18.00 \\
12.09 \\
15.10\end{array}$ & 0.81 & 0.01 \\
\hline Sulfadimethoxine & $\begin{array}{r}50.00 \\
100.00 \\
150.00\end{array}$ & $\begin{array}{r}109.27 \\
86.14 \\
91.88\end{array}$ & $\begin{array}{l}19.04 \\
13.12 \\
22.13\end{array}$ & 1.35 & 0.04 \\
\hline Sulfaquinoxaline & $\begin{array}{c}50.00 \\
100.00 \\
150.00\end{array}$ & $\begin{array}{r}116.02 \\
86.07 \\
92.03\end{array}$ & $\begin{array}{l}18.55 \\
15.59 \\
27.15\end{array}$ & 0.33 & 0.01 \\
\hline
\end{tabular}

Slope a: slope of calibration curve in solution; Slope b: slope of calibration curve in matrix. 
After building three calibration curves, decision limit $(\mathrm{CC} \alpha)$ and detection capability $(\mathrm{CC} \beta)$ were calculated. $\mathrm{CC} \alpha$ is calculated by the corresponding concentration at MRL plus 1.64 times the standard deviation of the within-laboratory reproducibility, and CC $\beta$ is the value of $\mathrm{CC} \alpha$ plus 1.64 times the standard deviation of the withinlaboratory reproducibility. These criteria are in accordance to the EU directive for the analytical methods validation procedure. ${ }^{55}$ The results are near the MRL $\left(100 \mathrm{ng} \mathrm{g}^{-1}\right)$ (Figure 4).

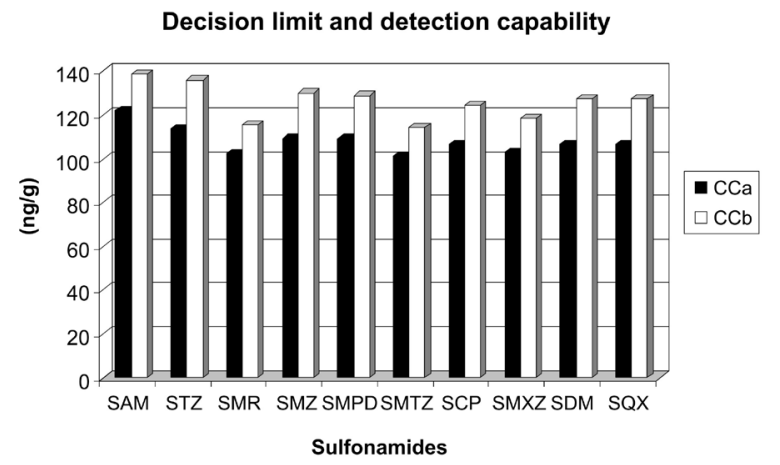

Figure 4. Decision limit $(\mathrm{CC} \alpha)$ and detection capability $(\mathrm{CC} \beta)$ results, for the ten sulfonamides analyzed by LC-ESI-MS/MS $\left(\mathrm{C}_{18}\right.$ column $150 \times 4.6 \mathrm{~mm}, 5 \mu \mathrm{m}$; gradient elution with water and acetonitrile both with $0.1 \%$ of formic acid; flow of $1 \mathrm{~mL} \mathrm{~min}{ }^{-1}$ ).

\section{Conclusions}

LC conditions were the same for both HPLC and LC-MS/MS equipment and they can be used for screening and for confirmation. This analytical method using LC-MS/MS with ESI ion source and triple quadrupole mass analyzer can be used indeed to identify and quantify sulfonamides residues in eggs based on the Commission of the European Communities, Commission Decision 2002/657/EC. It has a simple and rapid sample preparation $(4 \mathrm{~h})$ and uses only a small organic solvent volume $(4 \mathrm{~mL}$ of acetonitrile). The high-throughput and specificity regarding the use of LC-MS/MS, lead to fast methods that can be applied for continuous analysis on regulated laboratories. The validation of the method allows its use for quality control of eggs to match the present international food control regulations representing a great improvement to consumer's safety.

\section{Acknowledgments}

The authors would like to thank all staff from the Application Laboratory of Applied Biosystems/MDS Analytical Technologies, São Paulo, SP, Brazil, for access to the LC-MS/MS API 5000. We also thank CNPq, FUJB and FAPERJ.

\section{References}

1. Msagati, T. A. M.; Nindi, M. M.; Talanta 2004, 64, 87.

2. Stoev, G.; Michailova, A.; J. Chromatogr., A 2000, 871, 37.

3. Pang, G. F.; Cao, Y. Z.; Fan, C. L.; Zhang, J.; Li, X.; Li, Z.; Jia, G.; Anal. Bioanal. Chem. 2003, 376, 534.

4. Maudens, K. E.; Zhang, G-F.; Lambert, W. E.; J. Chromatogr., A 2004, 1047, 85.

5. Salisbury, C. D. C.; Sweet, J. C.; Munro, R.; J. AOAC Int. 2004, 87, 1264.

6. Posyniak, A.; Zmudzki, J.; Mitrowska, K.; J. Chromatogr., A 2005, 1087, 259.

7. Ashraf-Khorassani, M.; Taylor, L. T.; J. AOAC Int. 1996, 79, 1043.

8. Din, N.; Bartle, K. D.; Clifford, A. C.; Mccormack, A.; Castle, L.; J. Chromatogr. Sci. 1997, 35, 31.

9. Noa, M.; Perez, N.; Gutierrez, R.; Escobar, I.; Diaz, G.; Vega, S.; Prado, G.; Urban, G.; J. AOAC Int. 2002, 85, 1415.

10. Wen, Y.; Zhang, M.; Zhao, Q.; Feng, Y.; J. Agric. Food Chem. 2005, 53, 8468.

11. Pensabene, J. W.; Fiddler, W.; Parks, O. W.; J. Chromatogr. Sci. 1997, 35, 270.

12. Maxwell, R. J.; Lightfield, A. R.; J. Chromatogr., B: Anal. Technol. Biomed. Life Sci. 1998, 715, 431.

13. Caballero, R. D.; Torres-Lapasió, J. R.; Baeza-Baeza, J. J.; García-Alvarez-Coque, M. C.; J. Liq. Chromatogr. Relat. Technol. 2001, 24, 117.

14. Pecorelli, I.; Bibi, R.; Fioroni, L.; Galarini, R.; J. Chromatogr., A 2004, 1032, 23.

15. Hela, W.; Brandtner, M.; Widek, R.; Schuh, R.; Food Chem. 2003, 83, 601.

16. Furusawa, N.; Chromatographia 1999, 49, 369.

17. Furusawa, N.; Fresenius J. Anal. Chem. 1999, 364, 270.

18. Furusawa, N.; J. Liq. Chromatogr. Relat. Technol. 2000, 23, 1413.

19. Furusawa, N.; J. Chromatogr., A 2000, 898, 185.

20. Furusawa, N.; Kishida, K.; Fresenius J. Anal. Chem. 2001, 371, 1031.

21. Furusawa, N.; Vet. Res. Commun. 2001, 25, 651.

22. Furusawa, N.; J. Vet. Med. 2001, 48, 147.

23. Furusawa, N.; J. AOAC Int. 2002, 85, 848.

24. Furusawa, N.; Hanabusa, R.; Food Res. Int. 2002, 35, 37.

25. Furusawa, N.; Chromatographia 2003, 57, 317.

26. Furusawa, N.; Anal. Chim. Acta. 2003, 481, 255.

27. Furusawa, N.; J. Chromatogr., A 2007, 1172, 92.

28. Gehring, T. A.; Rushing, L. G.; Chrchwell, M. I.; Doerge, D. R. D.; Mcerlane, K. M.; Thompson, H. C.; J. Agric. Food Chem. 1996, 44, 3164.

29. Casetta, B.; Cozzani, R.; Cinquina, A. L.; Di Marzio, S.; Rapid Commun. Mass Spectrom. 1996, 10, 1497.

30. Volmer, D. A.; Rapid Commun. Mass Spectrom. 1996, 10, 1615. 
31. Combs, M. T.; Ashraf-Khorassani, M.; Taylor, L. T.; J. Pharm. Biomed. Anal. 1999, 25, 301.

32. Kim, D.; Lee, D. W.; J. Chromatogr., A 2003, 984, 153.

33. Dost, K.; Jones, D. C.; Davidson, G.; Analyst 2000, 125, 1243.

34. Di Corcia, A.; Nazzari, M.; J. Chromatogr., A 2002, 974, 53.

35. Fuh, M.; Chan, S.; Talanta 2001, 55, 1127.

36. Kim, D.; Choi, J.; Kim, J. S.; Lee, D. W.; Bull. Korean Chem. Soc. 2002, 23, 1590.

37. Cavaliere, C.; Curini, R.; Di Corcia, A.; Nazzari, M.; Samperi, R.; J. Agric. Food Chem. 2003, 51, 558.

38. Bogialli, S.; Curini, R.; Di Corcia, A.; Nazzari, M.; Samperi, R.; Anal. Chem. 2003, 75, 1798.

39. Bogialli, S.; Curini, R.; Di Corcia, A.; Nazzari, M.; Polci, M. L.; J. Agric. Food Chem. 2003, 51, 4225.

40. Verzegnassi, L.; Savoy-Perroud, M.-C.; Stadler, R. H.; J. Chromatogr., A 2002, 977, 77.

41. Rhijn, J. A. V.; Lasaronns, J. J. P.; Berendsen, B. J. A.; Brinkman, U. A. J.; J. Chromatogr., A 2002, 960, 121.

42. Ito, Y.; Oka, H.; Ikai, Y.; Matsumoto, H.; Miyazaki, Y.; Nagase, H.; J. Chromatogr., A 2000, 898, 95.

43. Gentili, A.; Perret, D.; Marchese, S.; Sergi, M.; Curini, R.; J. Agric. Food Chem. 2004, 52, 4614.

44. Shao, B.; Dong, D.; Wu, Y.; Hu, J.; Meng, J.; Tu, X.; Xu, S.; Anal. Chim. Acta 2005, 546, 174.

45. Thompson, T. S.; Noot, D. K.; Anal. Chim. Acta 2005, 551, 168.

46. Pang, G.; Cao, Y.; Zhang, J.; Jia, G.; Fan, C.; Li, X.; Liu, Y.; Li, Z.; Shi, Y.; J. AOAC Int. 2005, 88, 1304.

47. Clark, S. B.; Turnipseed, S. B.; Madson, M. R.; Hurlbut, J. A.; Kuck, L. R.; Sofos, J. N.; J. AOAC Int. 2005, 88, 736.
48. Carreteo, V.; Blasco, C.; Picó, Y.; J. Chromatogr., A 2008, 1209 , 162.

49. Sheridan, R.; Policastro, B.; Thomas, S.; Rice, D.; J. Agric. Food Chem. 2008, 56, 3509.

50. Lopez, M. I.; Pettis, J. S.; Smith, I. B.; Chu, P. S.; J. Agric. Food Chem. 2008, 56, 1553.

51. Bohm, D. A.; Stachel, C. S.; Gowik, P.; J. Chromatogr., A 2009 , $1216,8217$.

52. Smith, S.; Gieseker, C.; Reimschuessel, R.; Decker, C. S.; Carson, M. C.; J. Chromatogr., A 2009, 1216, 8224.

53. Heller, D. N.; Ngoh, M. A.; Donoghue, D.; Podhorniak, L.; Righter, H.; Thomas, M. H.; J. Chromatogr., B: Anal. Technol. Biomed. Life Sci. 2002, 774, 39.

54. Heller, D. N.; Nochetro, C. B.; Rummel, N. G.; Thomas, M. H.; J. Agric. Food Chem. 2006, 54, 52.

55. Commission Decision 2002/657/EC of 12 August 2002; Off. J. Eur. Commun. 2002, L221, 8.

56. Kan, C. A.; Petz, M.; J. Agric. Food Chem. 2000, 48, 6397.

57. Dahlmann, J.; Luckas, B.; Application Note of Applied Biosystems 2005, publication 114AP42-01.

58. Council Directive 96/23/EC of 29 April 1996; Off. J. Eur. Commun. 1996, L125, 10.

Submitted: March 31, 2010

Published online: October 21, 2010

FAPESP has sponsored the publication of this article. 